\title{
THE ERUPTION OF VESUVIUS IN AD 79 AND THE DEATH OF GAIUS PLINIUS SECUNDUS
}

\begin{abstract}
The effect of the volcanic eruption of Vesuvius in AD 79, which led inter alia to the death of Pliny the Elder, is reviewed. Pliny, the admiral of the Roman imperial fleet, wished as scientist to witness the event from close by and set sail in the direction of Vesuvius, but got trapped in Stabiae, a few kilometers from Pompeii, where he died together with thousands of inhabitants of nearby villages. Various reasons have been advanced to account for his death (asphyxiation caused by respiratory problems, carbon dioxide poisoning, heart failure, advanced coronary sclerosis). Basing our findings on the description of the catastrophe in the letters of his nephew, the younger Pliny, we believe that the most probable diagnosis which also fits his description of his uncle's behaviour and symptoms during his last hours, is that of acute and fatal bronchoconstriction in a chronic asthmatic.
\end{abstract}

\section{INTRODUCTION}

On 24 August AD 79 Vesuvius erupted, burying neighbouring Pompeii in ashes, stones and pumice, Herculaneum in volcanic mud, and Stabiae in ashes. Thousands of people lost their lives in this disaster. This was the second recorded eruption, the first being on 5 February AD $63 .{ }^{1}$ In the centuries thereafter Vesuvius has erupted nearly 50 times, most recently during the Allied invasion in 1944. Due to its inactivity the past 60 years, this volcano is at present the primary geological worry of Europe because of its potential explosivity: c. 1,5 million people live in the vicinity of the mountain.

The eruption of AD 79 is described vividly by an eye-witness, Pliny the Younger, in two letters to the historian Tacitus (Epistulae 6.16 and 20), in response to the latter's enquiry about the death of Pliny's uncle, Pliny the Elder, during the catastrophe. ${ }^{2}$

1 Thus recorded by Tacitus Annals 15.22-23. For literature on subsequent eruptions in antiquity, cf. Sherwin-White (1966:372).

2 Cf. the articles of Sullivan (1968:196-200), Sigurdsson et al. (1982:39-51) and Bisel (1987:11-23) in which the authors attempt to bring the information given by Pliny in line with modern volcanology. Bisel compares the eruption of Vesuvius in AD 79 with that of Mt. St. Helens, a similar but smaller volcano in the U.S.A. 


\section{THE ERUPTION OF AD 79}

The elder Pliny was at the time of the eruption the admiral of the imperial fleet at Misenum at the northern end of the Bay of Naples. Wishing as a scientist to get a closer view of the mountain, he ordered a light vessel to be prepared, but when he received an appeal for help from a friend trapped at the foot of the mountain, he changed his plan and ordered large galleys to proceed to Vesuvius to rescue the endangered people along the thickly populated coast. However, when his large vessel could not dock at Herculaneum or Pompeii (either because of the seismic elevation of the sea-bed or the landslide of volcanic mud streaming down from the slopes of Vesuvius into Herculaneum and on into the sea), Pliny continued further along the coast to Stabiae, a town a few kilometers south of Pompeii. Having sailed in with a favourable wind from the north west, he found that they could not leave again because of the contrary wind. After spending a terrifying night in the house of his friend Pomponianus (with only the elder Pliny sleeping soundly), they decided to move out into the open, fearing to be barricaded by the rising level of the ashes and pumice stones or crushed by falling building material in the continual earth tremors. As it happened, Stabiae and Pompeii were spared the flow of volcanic lava, ${ }^{3}$ but the heavy showers of ashes proved to be equally devastating and completely buried the two towns with a layer of ashes up to $6 \mathrm{~m}$. deep, crushing buildings by its weight. In fact, even those who managed to reach the open were in danger of being overwhelmed by the rain of ashes, as is evident from the younger Pliny's description of their experiences at Misenum, which is about 38 kilometers from Vesuvius - and thus way out of the focal point:

We rose from time to time and shook it [the ashes] off, otherwise we would have been buried and crushed beneath its weight (Epistula 6.20.16, own translation).

The younger Pliny who did not accompany his uncle but stayed at Misenum, received news of the elder Pliny's death from Pomponianus and the slaves who managed to escape. He describes his uncle's last hours as follows:

3 What geographers call a "Vesuvian eruption" produces steam, dust and stone, and sometimes streams of lava, absent in this occasion (Sherwin-White 1969:129). 


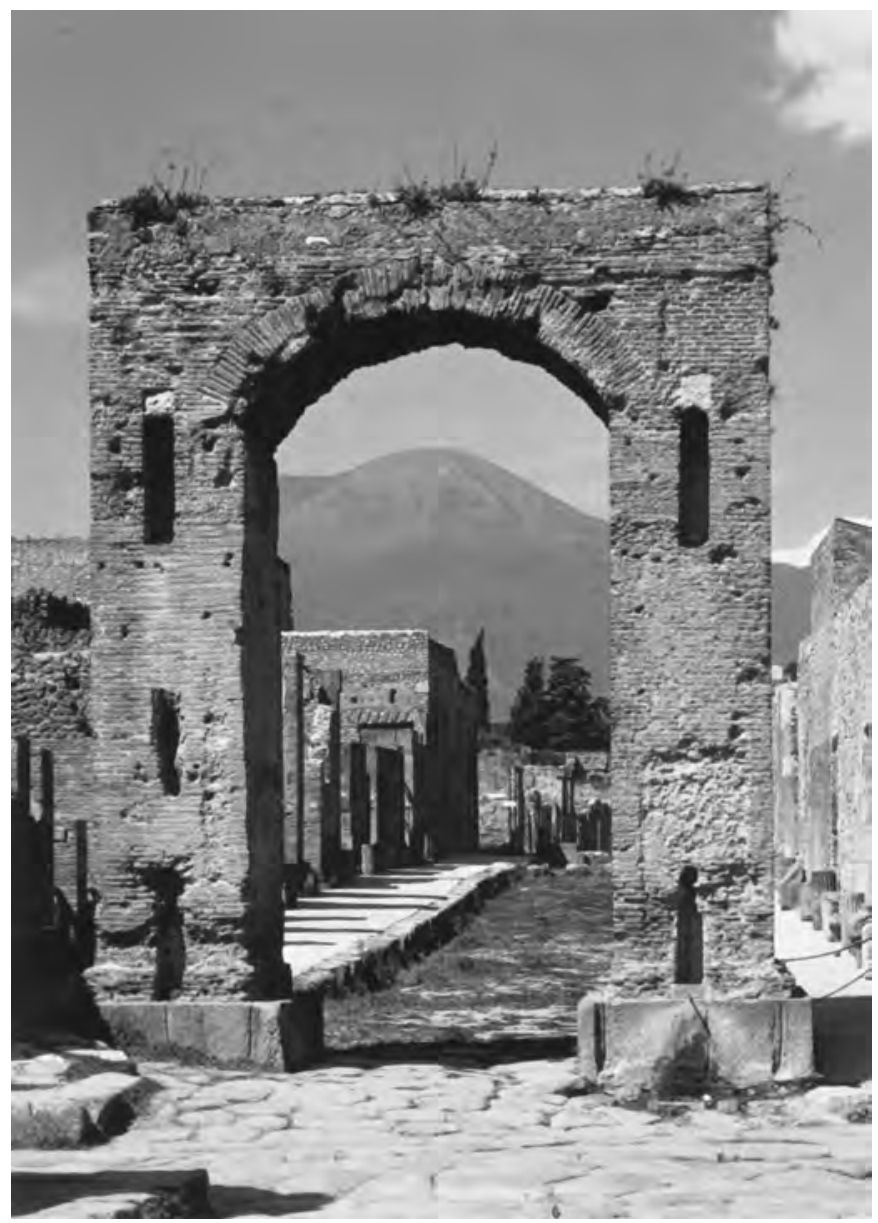

Figure 21: The Arch of Caligula in the Forum of Pompeii, with Vesuvius in the background.

They decided to go to the shore and investigate on the spot whether the sea admitted any escape, but it remained wild and dangerous. There, lying down on a sheet which was spread on the ground, he (i.e. Pliny the Elder) repeatedly asked for cold water to drink. Then the flames and the precursor of the flames, the smell of sulphur, drove the others to take flight and roused him. He got up, leaning on two slaves, and immediately collapsed, as I imagine, because the 
dense fog choked his breathing and blocked his trachea, which was by nature weak and narrow and often inflamed. When daylight returned (the third day after the last day he had seen), his body was found intact and uninjured and still fully clothed, and looking more like a person sleeping than one who had died.

(Ep. 6.16.17-20, own translation).

\section{THE DEATH OF PLINY: DIAGNOSES}

Various reasons have been advanced to account for the death of Pliny the Elder. In his letter the younger Pliny obviously wishes to portray his uncle as the great humanitarian sacrificing his own life in his attempt to rescue those endangered by the eruption, with the result that one may expect that some details may have been omitted or over-emphasised. However, his diagnosis seems to be objective and probably as close to relevant as can be expected in the $1^{\text {st }} / 2^{\text {nd }}$ century $A D$ : asphyxiation brought about by respiratory problems. This diagnosis is in fact to a great extent echoed by most scholars. ${ }^{4}$ Sherwin-White (1966:374), referring to a passage earlier on in the same letter, further remarks:

He was perhaps asthmatical, whence the heavy snores ${ }^{5}$ of par. 13, and died the more quickly, like victims of London 'smog'.

4 Bisel (1987:12-13), a pathologist, examined the skeletons of the victims found on the beach front of Herculaneum, and came to the conclusion that a ground surge of hot ash and gas, moving at high speed, must have overpowered and asphyxiated the Herculaneans almost immediately. Since, however, excavations have revealed that the towns around Vesuvius had different kinds of deposits which would have depended on i.a. the direction of the wind and the distance from the volcano, the reasons for the death of the victims would not necessarily have been the same in the different regions. Basing his diagnosis on Pliny's description of the showers of ashes in Stabiae, Ziegler (1893-1963:Vol. XXI, pp. 283-284) ascribes the death of the elder Pliny to an obstruction in the trachea. Grmek (1987:35) and Van der Paardt (1991:59) reject this theory of asphyxiation, since a person who had choked to death would, according to them, not have had a peaceful facial expression. From a purely medical point of view, however, this is possible, since the facial muscles relax at death.

5 Pliny the Younger ascribes the snoring during the night spent at Stabiae to the fact that his uncle was a stout man (per amplitudinem corporis). The fact that Pliny uses the periphrasis meatus animi ... gravior et sonantior ("his breathing was rather laboured and loud") to describe his uncle's snoring instead of the usual verb stertere, could be seen as an indication of his serious asthmatic condition. 


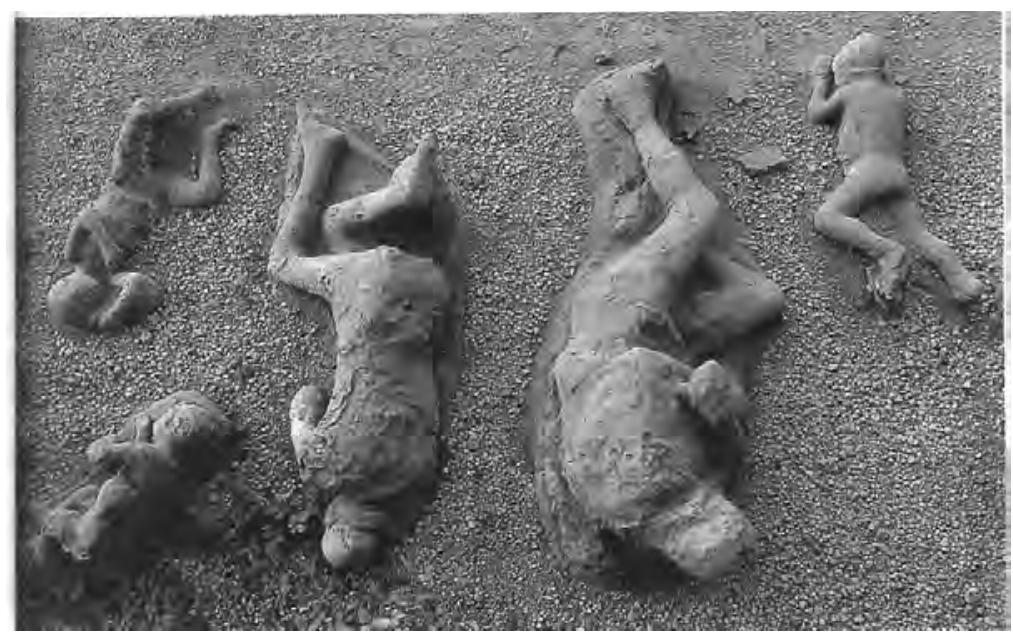

Figure 22: Plastercasts of victims, Pompeii.

The possibility of carbon dioxide poisoning has also been mentioned (Van der Paardt 1991:59), but is queried by several scholars on the ground that other people would also have been affected by it in some way or other. Schönberger's objection (1990:548) that the poisonous gases could not have reached Stabiae because the wind was not blowing from the direction of the mountain, is not valid, since it is clear from Epistula 6.20.11 (where the younger Pliny describes how the view of the island of Capri had been blotted out by a dark cloud) that the wind had swung round and was now blowing from the mountain, that is, from the north east.

Another theory which has been put forward is heart failure. L. Sprague de Camp (1963:225) gives the following reason for Pliny's death:

... while waiting to embark, Plinius suddenly fell dead. He was fat, asthmatic and in his fifties, and all this scrambling about through a rain of volcanic debris had been too much for his heart.

This is also the view of Grmek (1987:42), who points out that a sudden death due to a heart attack is usually the result of circumstances which require an enormous physical effort or which provoke a violent emotion. Both these factors were present during the last exploit of the elder Pliny: 
violent emotion in the face of a terrifying spectacle and of an admiral suddenly confronted with tremendous responsibility, and the unusual physical effort to rush from Pomponianus's villa to the beach.

Related to this theory is that of Schönberger (1990:529), whose diagnosis is death due to advanced coronary sclerosis. He motivates his view by saying that one should not take seriously the Younger Pliny's view that his uncle's bath and rest after their arrival at Stabiae was a nonchalant pose adopted to counteract the panic of his friends. Does one take a bath, he asks, to calm down one's friends during a volcanic eruption? He points out that the elder Pliny undertook nothing active after his arrival, and this, he believes, is what one expects of a person who suffers from advanced coronary sclerosis. ${ }^{6}$ However, coronary heart disease as recognised today seems to have been an unknown entity in the $1^{\text {st }}$ century $\mathrm{AD}$. It is not mentioned by Hippocrates; in fact, even in modern times the classic picture of coronary thrombosis in Europe was described by Herrick only as recently as 1912 (Wood 1956:701). The short life-span of man in Roman times - on average less than 30 years (Saller 1994:41) — could be partially responsible.

Although Grmek's theory of a heart attack is attractive, the authors of this article believe that the most probable diagnosis from a medical point of view which also fits the description given in Epistula 6.16 by Pliny the Younger of his uncle's behaviour and symptoms during his last hours, is that of acute and fatal bronchoconstriction in a chronic asthmatic. Pliny the Younger himself states that his uncle had a longstanding respiratory problem, a "trachea which was by nature weak and narrow and often inflamed". It is well known that asthmatics have hypersensitive lung tissue which will react adversely to external stimuli innocuous or only mildly irritating to non-asthmatic subjects. Although the smoke from Vesuvius (12 km away) would have contained many toxic substances, the "smell of sulphur", specifically mentioned, probably indicated the presence of gases such as sulphur dioxide (even sulphur trioxide) and hydrogen sulphide, particularly noxious to the respiratory mucosa of a asthmatic like Pliny the Elder (Johns 1966:1416). He could thus have died of acute asthma while Pomponianus, the slaves and other companions on the beach survived.

This is also the view of Zirkle (1967:533). 


\section{VERDICT: JUDGEMENT RESERVED}

It is interesting to note the rumour recorded by Suetonius (De historicis fr. 80) that Pliny eventually died by the hand of a slave whom he requested to kill him when the progressive asphyxiation became unbearable. There is furthermore the possibility of suicide: ${ }^{7}$ the admiral, unable to face the disaster of his failing strength, would sacrifice himself to make the task of his companions easier, and to prevent them from witnessing his agony. Both possibilities would of course be contradictory to the younger Pliny's description that the body of his uncle was found intact and uninjured. However, it has already been argued (vide supra) that the former set out to portray his uncle's death in heroic fashion - Grmek (1987:42) aptly refers to this letter as a laudatio funebris (a eulogy usually held at a funeral) — and these suggestions would certainly detract from this image. One could indeed ask why a person of Pliny's stature, obviously unwell, would have been left alone on that fateful night. He had slaves to assist him - he obviously tried unsuccessfully to walk, but why was he not carried to safety by those who accompanied him (and survived the ordeal)? The information we have is not only limited, but also second hand. In spite of the young nephew's assurance that his uncle was found "looking more like a person sleeping than one who had died", there seems to be little doubt that Pliny the Elder died a lonely and dreadful death on the beach at Stabiae.

\section{REFERENCES}

BISEL S

1987. The people of Herculaneum, A.D. 79. In: J. Pigeaud \& J. Oroz (eds.), Pline l'ancien. Témoin de son temps (Nantes: Salamanca).

\section{GRMEK M D}

1987. Les circonstances de la mort de Pline: Commentaire medical d'une lettre destinée aux historiens. In: J. Pigeaud \& J. Oroz (eds.), Pline 1'ancien. Témoin de son temps (Nantes: Salamanca).

$7 \quad$ Mentioned by Grmek (1987:33). 
1991. Diseases in the ancient Greek world (transl. M. \& L. Muellner). Baltimore \& London: The Johns Hopkins University Press.

JOHNS R J

1966. Harrison's principles of internal medicine. $5^{\text {th }}$ ed. MacGraw-Hill.

Pigeaud J \& Oroz J (EDs.)

1987. Pline 1'ancien. Témoin de son temps. Nantes: Salamanca.

\section{SALLER R}

1994. Patriarchy, property and death in the Roman family. Cambridge: Cambridge University Press.

\section{SCHÖNBERGER O}

1990. Die Vesuv-Briefe des jöngeren Plinius (V.16 und 20). Gymnasium 97:526548.

\section{SHERWIN-WHite A N}

1966. The letters of Pliny. Oxford: Oxford University Press.

1969. Fifty letters of Pliny. Oxford: Oxford University Press.

\section{Sigurdsson H, Cashdollar S \& SPARKS S R J}

1982. The eruption of Vesuvius in A.D. 79: historical and volcanological evidence. American Journal of Archaeology 86:39-51.

\section{SPRAGUE DE CAMP L}

1963. Ancient engineer. New York: Doubleday.

\section{SulLIVAN F A}

1968. Pliny Epistulae 6.16 and 20 and modern volcanology. Classical Philology 63:196-200.

\section{VAN DER PAARDT R TH}

1991. Plinius als verslaggever? Lampas 24(1):54-65.

\section{WoOD P}

1956. Diseases of the heart and circulation. $2^{\text {nd }} \mathrm{ed}$. London: Eyre \& Spottiswoode.

\section{ZIEGLER K}

1893-1963. Plinius. In: Paulys Realencyclopädie der classischen Altertumswissenschaft.

Band XXI, Stuttgart: Metzlersche Verlagsbuchhandlung, pp. 283-284.

\section{ZIRKLE C}

1967. The death of Gaius Plinius Secundus. Isis 58:553-559. 